\title{
CALLING ALL BIRDERS
}

One way to enhance your birding fun is by taking part in a scientific project - simply by looking more closely at all individuals you see of the following five species. Some of each are wearing coloured legbands or have had coloured plastic tags attached to a wing to determine their movements. Finding one would be a major achievement - in the same category as finding a very rare bird or the needle in a haystack. Reporting one will be a significant contribution to the project.

You can report observations directly to the project leader or to Bernie Gollop for forwarding at 2202 York Ave., Saskatoon SK S7J 1J1; phone (306) 343-1027; fax (306) 2424756, or e-mail to Marshall.Gilliland@USASK.ca. For legbands this means which colour is on top (if more than one) and which leg(s) they are on; for wing tags, which wing.

American Bitterns with coloured wing tags are from the Agassiz National Wildlife Refuge in Minnesota. Phone (218) 449-4115.

More than 3000 White-faced Ibis have been colour-banded with two legbands in the Great Basin, Nevada. Eric Kelchin, USF\&W, Stillwater National Wildlife Refuge, Fallon, Nevada 89406-1236; or phone (702) 423-5128.

Willets have been banded in Oregon with coloured legbands and wing flags. David Mehlman, NBS-FRESC, 3200 SW Jefferson Way, Corvallis, Oregon 97331, or call (541) $750-7495$, or fax (541) $758-7761$, or e-mail to mehlman@fsl.orst.edu.

Semipalmated Sandpipers were colour-banded in Delaware Bay, Delaware, with a combination of bands and flags. David Mizrahi, Department of Biological Sciences, Box 341903, Clemson University, Clemson, South Carolina 29634-1903, or call (864) 656-3585, or fax (864) 656-0435 or e-mail at dmizrah@hubcap.clemson.edu.

Ring-billed Gulls were colour legbanded in western New York. John M. Peterson, High Peaks Audubon Society, RR 1, Box 230, Elizabethtown NY 12932-9721 or call (518) 873-2052.

- From Bird Watcher's Digest, Jan/Feb 1997. 